\title{
Efektivitas air rebusan bawang dayak (Eleutherine palmifolia (L.) Merr) dalam menghambat pertumbuhan bakteri Escherichia coli pada daging sapi
}

\author{
Effectiveness of boiled water of dayak onion (Eleutherine palmifolia (L.) Merr) to \\ inhibiting the growth of Escherichia coli bacteria in beef
}

Mey Angraeni Tamal ${ }^{1 *}$, Dhani Aryanto ${ }^{1)}$

${ }^{1}$ Sekolah Tinggi Pertanian Kutai Timur

Jl. Soekarno-Hatta No. 1 Sangatta Kutai Timur, Kalimantan Timur Kode Pos 75387

*Email: mey.angraeni@stiperkutim.ac.id

Diterima: 13/02/2020; ditinjau: 15/02/2020; disetujui: 20/03/2020

\begin{abstract}
At this time many food processing used chemical preservatives that can interfered human health. Dayak onion plants was widely used as medicine because they contain antimicrobial substances. Efforts to increase the used of natural preservatives from plants so that plants would be able to replace chemical preservatives. However, this plant had not been used as a natural preservative so there was a need for research to increase knowledge of other benefits, especially as preservatives for stored livestock products. The purpose of this study is to determine the best concentration of boiled water of dayak onion (Eleutherine palmifolia (L.) Merr) to inhibiting the growth of Escherichia coli bacteria and how long the meat has been stored is still in good condition at room temperature and how much was the best concentration of boiled water of Dayak onions. The method used was descriptive analysis. The stages of the study were the manufactured of boiled water of dayak onion 0, 10, 20 and 30\% w/v, soaked for 15 minutes, packed, storaged at room temperature 22-32 ${ }^{\circ} \mathrm{C}$ and E. coli tested at the Animal Health and Veterinary Public Health Laboratory of Samarinda. The results of the study were boiled water of dayak onion had an effect as an antimicrobial agent at a concentration of $30 \% \mathrm{w} / \mathrm{v}$, there was a tendency to reduced the number of E. coli bacterial colonies in beef and the best storaged treatment was 1 day. Keywords : boiled water of dayak onion, Escherichia coli, concentration, beef, an antimicrobial agent
\end{abstract}

\begin{abstract}
ABSTRAK
Pada saat ini pengolahan pangan banyak menggunakan bahan pengawet kimia yang dapat mengganggu kesehatan manusia. Tanaman bawang dayak banyak dimanfaatkan sebagai obat karena mengandung zat anti mikroba. Upaya untuk meningkatkan penggunaan bahan pengawet alami dari tanaman sehingga bahan ini yang akan dapat mengganti bahan pengawet kimia. Namun tanaman ini belum dimanfaatkan sebagai bahan pengawet alami sehingga perlu adanya penelitian untuk menambah pengetahuan akan manfaat lain khususnya sebagai bahan pengawet pangan hasil ternak sehingga lebih tahan lama ketika disimpan. Penelitian bertujuan untuk mengetahui efek bawang dayak sebagai zat anti mikroba dalam menghambat pertumbuhan bakteri Escherichia coli (E. coli) serta berapa lama daging disimpan masih dalam kondisi baik pada suhu kamar serta berapa konsentrasi air rebusan bawang dayak yang terbaik. Analisis yang digunakan adalah deskriptif. Pembuatan air rebusan bawang dayak $0 \% \mathrm{~b} / \mathrm{v}, 10 \% \mathrm{~b} / \mathrm{v}$,
\end{abstract}


$20 \% \mathrm{~b} / \mathrm{v}$ dan $30 \% \mathrm{~b} / \mathrm{v}$ kemudian perendaman daging selama 15 menit dilanjutkan dengan pengepakan serta disimpan pada suhu ruang $22-32{ }^{\circ} \mathrm{C}$. Setelah proses penyimpanan dilanjutkan dengan analisis uji E. coli di Laboratorium Kesehatan Hewan dan Kesehatan Masyarakat Veteriner Samarinda. Hasil yang diperoleh pada penelitian ini adalah air rebusan bawang dayak memiliki efek sebagai zat anti mikroba karena pada konsentrasi $30 \%$ ada kecenderungan menurunkan jumlah koloni bakteri E. coli pada daging sapi sedangkan perlakuan penyimpanan yang terbaik adalah 1 hari masih dalam kondisi baik dan tidak busuk.

Kata kunci : air rebusan bawang dayak, Escherichia coli, konsentrasi, daging sapi, zat anti mikroba

\section{PENDAHULUAN}

Manusia membutuhkan makanan untuk hidup karena merupakan kebutuhan yang pokok untuk tumbuh dan berkembang serta memperbaiki sel-sel tubuh yang rusak. Pangan yang kita makan berasal dari tanaman dan hewan yang kebutuhannya meningkat seiring dengan pertumbuhan penduduk dunia, sehingga produksi tanaman dan hewan juga harus ditingkatkan.

Meningkatkan produksi pangan juga diiringi dengan penanganan pasca panen karena pangan tersebut mudah rusak salah satunya adalah daging, oleh karena itu perlu adanya bahan pengawet untuk mengawetkan pangan tersebut. Bahan Pengawet tersebut merupakan bahan tambahan yang dimasukkan ke dalam pangan dengan tujuan memperpanjang masa simpan. Menurut Saparinto dan Hidayati (2006) bahan tambahan pangan adalah bahan yang ditambahkan secara sengaja ke dalam makanan untuk mempengaruhi sifat dan bentuk pangan. Bahan ini digunakan untuk memperbaiki citarasa, warna, bentuk dan memperpanjang masa simpan
Saat ini bahan pengawet dari bahan kimia sering diberikan ke pangan agar tahan lama ketika disimpan, tetapi hal itu berbahaya karena dapat mengganggu kesehatan manusia, oleh karena itu perlu adanya upaya untuk meningkatkan penggunaan bahan pengawet alami dari tanaman sehingga bahan ini yang akan banyak digunakan sebagai mengawetkan pangan. Tanaman yang saat ini kurang pemanfaatannya adalah bawang dayak, kebanyakan bawang dayak digunakan sebagai obat karena mengandung zat anti mikroba tetapi pemanfaatan yang lain hampir belum tersentuh sehingga perlu penelitian untuk menambah pengetahuan akan manfaat bawang dayak khususnya sebagai bahan pengawet terutama pada pangan hasil ternak yang mudah rusak.

Bawang dayak dikenal juga dengan nama bawang tiwai dan banyak terdapat di Kalimantan. Orang dayak sering menggunakannya sebagai obat. Berdasarkan hasil penelitian Puspadewi, Adirestuti, dan Menawati (2013) tentang identifikasi zat fitokimia serbuk simplisia dan ekstrak Umbi Bawang Dayak sebagai berikut :

Tabel 1. Hasil penapisan fitokimia serbuk simplisia dan ekstrak umbi bawang dayak

\begin{tabular}{lccc} 
& \multirow{2}{*}{ Identifikasi } & \multicolumn{3}{c}{ Simplisia } \\
\cline { 2 - 4 } & Pengujian & Pustaka & Ekstrak \\
\hline Alkaloid & + & + & + \\
Flavonoid & + & + & + \\
Kuinon & + & + & + \\
Polifenol & + & + & + \\
Saponin & + & + & + \\
Steroid / Triterpenoid & + & + & + \\
Monoterpenoid / Seskuiterpen & + & + & + \\
Tanin & + & $:$ data dari pustaka inventaris tanaman obat Indonesia dan \\
Keterangan : & materia medika Indonesia tidak terdapat keterangan ada \\
(+) : adanya komponen zat yang diidentifikasi & & atau tidaknya senyawa tersebut.
\end{tabular}


Tabel 1. menunjukkan bahwa bawang dayak memiliki zat anti mikroba seperti flavonoid, kuonin, dan tannin sehingga dapat digunakan sebagai bahan pengawet. Menurut Naspia, Iskandar, dan Moektiwardoyo (2014) berdasarkan penelitian-penelitian yang telah dilakukan, umbi tanaman ini mempunyai berbagai aktivitas farmakologi, yaitu antioksidan, aktivitas tabir surya, antiinflamasi, antidiabetes, antiagregasi platelet, anti bakteri, antikanker, antijamur, dan antiamoeba, serta mempunyai toksisitas subakut pada jaringan hati tikus.

Berdasarkan banyaknya manfaat dan kegunaan bawang dayak sebagai obat maka pada penelitian ini ingin mengetahui bagaimana efek bawang dayak sebagai zat anti mikroba dalam menghambat pertumbuhan bakteri Escherichia coli (E. coli) pada daging sapi, berapa konsentrasi yang terbaik dan berapa lama daging disimpan masih dalam kondisi baik. Penelitian ini memberikan informasi kepada masyarakat akan manfaat air rebusan bawang dayak sebagai bahan pengawet.

\section{METODE PENELITIAN}

Penelitian telah dilaksanakan pada bulan Juli sampai Agustus Tahun 2019. Metode yang digunakan dalam penelitian ini adalah analisis secara deskriptif. Tahapan penelitian dimulai dengan pembelian daging sapi lalu pembuatan rebusan air bawang dayak $0 \% \mathrm{~b} / \mathrm{v}, 10 \% \mathrm{~b} / \mathrm{v}, 20 \% \mathrm{~b} / \mathrm{v}$ dan $30 \%$ $\mathrm{b} / \mathrm{v}$ dengan pengulangan sebanyak 5 kali kemudian perendaman daging selama 15 menit dilanjutkan dengan pengepakan serta disimpan pada suhu ruang $22-32{ }^{\circ} \mathrm{C}$. Setelah proses penyimpanan dilanjutkan dengan analisis uji E. coli di Laboratorium Kesehatan Hewan dan Kesehatan Masyarakat Veteriner Samarinda.

\section{HASIL DAN PEMBAHASAN}

\section{Analisis uji Escherichia coli}

Escherichia coli adalah bakteri yang berbentuk batang dan tergolong bakteri gram negatif yang dapat hidup pada suhu $20-40$
${ }^{0} \mathrm{C}$ dengan suhu optimum $37{ }^{0} \mathrm{C}$. Bakteri $E$. coli umumnya tidak berbahaya karena dapat ditemukan di dalam usus manusia maupun hewan. Hanya saja jika populasinya melebihi batas normal di pangan dapat menyebabkan diare dan keracunan dan apabila menjalar ke organ dapat menyebabkan infeksi. Menurut Sutiknowati (2016) menyatakan bahwa bakteri E. coli ditemukan pada tahun 1885 oleh Theodor Escherich dan diberi nama sesuai dengan nama penemunya. E. coli merupakan bakteri berbentuk batang dengan panjang sekitar 2 mikrometer dan diamater 0.5 mikrometer. Volume sel E. coli berkisar 0.6-0.7 m3. Bakteri ini dapat hidup pada rentang suhu 20-40 ${ }^{0} \mathrm{C}$ dengan suhu optimumnya pada $370 \mathrm{C}$ dan tergolong bakteri gram negatif, selanjutnya dikatakan bahwa kebanyakan E. coli tidak berbahaya, tetapi beberapa seperti E. coli tipe O157:H7 dapat mengakibatkan keracunan makanan yang serius pada manusia yaitu diare berdarah karena eksotoksin yang dihasilkan bernama verotoksin. Bakteri E. coli dalam jumlah yang berlebihan dapat mengakibatkan diare, dan bila bakteri ini menjalar ke sistem/organ tubuh yang lain, maka akan dapat menyebabkan infeksi.

Uji Escherichia coli dilakukan menggunakan media kit. Media ini merupakan media selektif khusus untuk biakan E. coli dan dengan mudah diidentifikasi karena menghasilkan warna hijau metalik (Gambar 1).

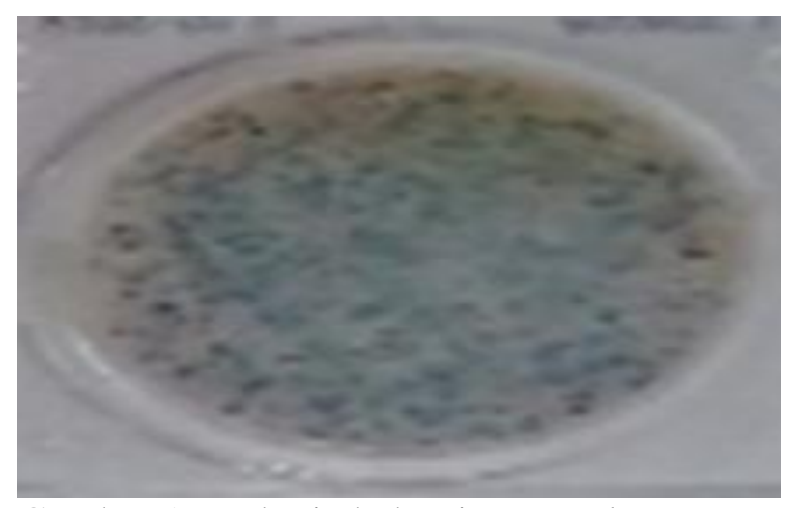

Gambar 1. Koloni bakteri E. coli menunjukkan warna hijau metalik pada media kit 


\section{Jumlah koloni/g cemaran bakteri Escherichia coli}

Daging adalah salah satu hasil ternak yang mudah rusak karena menjadi media pertumbuhan bakteri. Daging mengandung nutrisi seperti protein, karbohidrat, lemak, vitamin, dan mineral. Nutrisi tersebut dibutuhkan oleh mikroorganisme untuk tumbuh dan memperbanyak diri. Nutrisi daging yang lengkap menyebabkannya mudah mengalami kerusakan oleh mikroorganisme. Hal ini sejalan dengan Purnomo (2012) bahwa daging adalah salah satu hasil ternak yang mudah rusak, yang diakibatkan karena komposisi gizinya. Pada umumnya daging mengandung sekitar $75 \%$ air, $18 \%$ protein, $3 \%$ lemak, $1,5 \%$ senyawa nitrogen bukan protein serta vitamin dan mineral dalam jumlah sedikit. Kondisi komponen gizi yang cukup lengkap ini mengakibatkan daging mudah mengalami kerusakan terutama oleh kerja mikroorganisme.

Daging yang mudah rusak dilakukan proses pengawetan dengan perendaman dengan air rebusan bawang dayak selanjutnya pengujian terhadap bakteri Escherichia coli (E. coli) sehingga diperoleh data yang disajikan pada Tabel 2.

Tabel 2. Jumlah koloni/g cemaran bakteri Escherichia coli pada sampel daging sapi yang direndam dengan air rebusan bawang dayak (ARBD)

\begin{tabular}{|c|c|c|c|c|}
\hline \multirow{2}{*}{$\begin{array}{l}\text { Konsentrasi } \\
\text { air rebusan } \\
\text { bawang dayak }\end{array}$} & \multirow[b]{2}{*}{ Ulangan } & \multicolumn{3}{|c|}{ Penyimpanan } \\
\hline & & $\begin{array}{c}1 \text { Hari } \\
\Sigma \text { Koloni/g } \\
\end{array}$ & $\begin{array}{c}3 \text { Hari } \\
\Sigma \text { Koloni/g }\end{array}$ & $\begin{array}{c}5 \text { Hari } \\
\Sigma \text { Koloni/g }\end{array}$ \\
\hline \multirow{5}{*}{$0 \%$} & 1 & TBUD & 0 & 5 \\
\hline & 2 & $1.32 \times 10^{4}$ & TBUD & 0 \\
\hline & 3 & TBUD & $3.1 \times 10^{3}$ & 0 \\
\hline & 4 & $2.03 \times 10^{4}$ & 0 & 0 \\
\hline & 5 & TBUD & $7 \times 10^{2}$ & 0 \\
\hline \multirow{5}{*}{$10 \%$} & 1 & $7 \times 10^{4}$ & $1.09 \times 10^{4}$ & 0 \\
\hline & 2 & $1.64 \times 10^{5}$ & $1.15 \times 10^{4}$ & 0 \\
\hline & 3 & TBUD & $7.9 \times 10^{3}$ & 0 \\
\hline & 4 & $6.6 \times 10^{3}$ & $9 \times 10^{2}$ & $1.68 \times 10^{5}$ \\
\hline & 5 & $1.32 \times 10^{5}$ & $1.15 \times 10^{4}$ & $2.4 \times 10^{3}$ \\
\hline \multirow{5}{*}{$20 \%$} & 1 & TBUD & 0 & $3 \times 10^{3}$ \\
\hline & 2 & TBUD & 2 & 0 \\
\hline & 3 & $1.84 \times 10^{5}$ & $4.5 \times 10^{3}$ & $2.6 \times 10^{3}$ \\
\hline & 4 & TBUD & TBUD & 0 \\
\hline & 5 & $7.8 \times 10^{3}$ & 0 & 0 \\
\hline \multirow{5}{*}{$30 \%$} & 1 & $1.8 \times 10^{5}$ & TBUD & 0 \\
\hline & 2 & $1.84 \times 10^{5}$ & $5.6 \times 10^{3}$ & 0 \\
\hline & 3 & $1.88 \times 10^{5}$ & TBUD & $1.1 \times 10^{3}$ \\
\hline & 4 & $1.24 \times 10^{5}$ & TBUD & $2.5 \times 10^{3}$ \\
\hline & 5 & $1.84 \times 10^{5}$ & $1.01 \times 10^{4}$ & $1.25 \times 10^{4}$ \\
\hline & Untuk D & & & \\
\hline
\end{tabular}

\section{Jumlah koloni penyimpanan 1 hari}

Berdasarkan hasil yang telah diperoleh pada Tabel 1. diketahui bahwa jumlah koloni bakteri pada perlakuan penyimpanan 1 hari dengan konsentrasi Air Rebusan Bawang Dayak (ARBD) $0 \%, 10 \%$ dan $20 \%$ menunjukkan jumlah koloni sangat banyak hingga ada yang TBUD (Tidak Bisa Untuk Dihitung) sedangkan pada perlakuan $30 \%$, jumlah koloni masih bisa dihitung serta tidak ada yang TBUD. Berdasarkan hal tersebut konsentrasi ARBD $30 \%$ memperlihatkan jika koloni E.coli mengalami penurunan sehingga ada kecenderungan bahwa peningkatan konsentrasi air rebusan bawang dayak dapat menurunkan jumlah koloni bakteri. Diketahui bahwa bawang dayak memiliki anti mikroba alkaloid, glikosida, flavonoid, fenolik, steroid dan tannin sehingga mampu menghambat pertumbuhan bakteri. Yuniar dan Galingging (2009) bahwa bawang dayak atau bawang hantu 
(Eleutherine palmifolia (L.) Merr) merupakan tanaman khas Kalimantan Tengah. Tanaman ini sudah secara turun temurun dipergunakan masyarakat Dayak sebagai tanaman obat. Tanaman ini memiliki warna umbi merah dengan daun hijau berbentuk pita dan bunganya berwarna putih. Dalam umbi bawang dayak terkandung senyawa fitokimia yakni alkaloid, glikosida, flavonoid, fenolik, steroid dan tannin.

Pada setiap anti mikroba memiliki konsentrasi masing-masing untuk menghambat pertumbuhan bakteri. Apabila konsentrasi kurang atau rendah maka pertumbuhan bakteri masih bisa terjadi. Masih terdapatnya bakteri pada konsentrasi ARBD $10 \%, 20 \%$ dan $30 \%$ menunjukkan konsentrasinya masih rendah sehingga belum efektif menurunkan jumlah koloni bakteri ketika perlakuan penyimpanan sehingga kemungkinan kerusakan yang ditimbulkan oleh bahan pengawet tersebut bersifat mikrostatik. Menurut Koeswara (2009) bahwa keefektivan penghambatan merupakan salah satu kriteria pemilihan suatu senyawa anti mikroba untuk diaplikasikan sebagai bahan pengawet bahan pangan. Semakin kuat penghambatannya semakin efektif digunakan. Kerusakan yang ditimbulkan komponen anti mikroba dapat bersifat mikrosidal (kerusakan tetap) atau mikrostatik (kerusakan sementara yang dapat kembali). Suatu komponen akan bersifat mikrosidal atau mikrostatik tergantung pada konsentrasi dan kultur yang digunakan.

\section{Jumlah koloni penyimpanan 3 hari dan 5 hari}

Daging yang tidak direndam dengan ARBD pada perlakuan penyimpanan 1 hari menunjukkan jumlah koloni yang banyak, demikian pula daging yang direndam dengan ARBD $10 \%$ dan $20 \%$, tetapi kemudian mengalami penurunan jumlah koloni pada penyimpanan 3 hari, hal ini disebabkan bakteri mengalami fase pertumbuhan karena nutrisi melimpah di penyimpanan 1 hari sedangkan zat anti mikroba belum maksimal efeknya dalam menghambat pertumbuhan bakteri E. coli sehingga semakin lama penyimpanan, nutrisi, $\mathrm{pH}$, air, udara untuk pertumbuhan bakteri makin berkurang serta terjadi penumpukan hasil sisa zat metabolisme bakteri sehingga terjadi fase kematian yang terjadi pada tahap penyimpanan 5 hari jumlah koloni bakteri $E$. coli ditemukan hanya 5 koloni bahkan banyak yang 0 (tidak ada) koloni.

Pada konsentrasi ARBD $30 \%$ penyimpanan 1 hari jumlah koloni lebih sedikit dibandingkan penyimpanan 3 hari. Hal ini disebabkan pada penyimpanan 3 hari koloni meningkat hingga terjadi TBUD yaitu pada ulangan 1, 3 dan 4 . Kemudian terjadi penurunan jumlah koloni lagi pada penyimpanan 5 hari. Saat terjadi peningkatan jumlah koloni di penyimpanan 3 hari menunjukkan bahwa efek anti mikroba pada ARBD sudah hilang pada daging sapi.

Berdasarkan data dari Dinas Pertanian dan Peternakan Kabupaten Kutai Timur Tahun 2016 bahwa terdapat beberapa sampel daging dari pedagang yang ditemukan TBUD cemaran bakteri $E$. coli nya. Cemaran tersebut melebihi ambang batas maksimum sehingga tidak sesuai dengan Badan Standarisasi Nasional (2009) SNI 7388-2009 bahwa daging segar, beku (karkas dan tanpa tulang), dan daging cincang dengan jenis cemaran E.coli adalah $1 \times 10^{1}$ koloni/g.

Cemaran bakteri E. coli pada daging sapi menunjukkan cemaran yang cukup besar sehingga dibutuhkan zat anti mikroba yang memiliki daya hambat yang besar pula. Hasil Penelitian Istiansyah, Rahmawati, dan Ibrahim (2016), bahwa penentuaan Konsentrasi Hambat Tumbuh Minimum (KHTM) dilakukan menggunakan filtrat yang sudah dikeringkan. Ekstrak umbi bawang tiwai (bawang dayak) yang digunakan bervariasi antara $0.5 \%, 1 \%, 2 \%$, $4 \%, 8 \%, 12 \%$. Konsentrasi $0.5 \%$ merupakan konsentrasi terkecil dari ekstrak umbi bawang tiwai yang dapat menghambat pertumbuhan bakteri Escherichia coli dan Staphylococus aureus dan $12 \%$ sebagai konsentrasi terbesar, dengan variasi konsentrasi yang digunakan, semakin tinggi konsentrasi, zona hambatan semakin besar. 


\section{Persentase jumlah koloni}

Pada perlakuan penyimpanan dan perendaman daging dengan ARBD terdapat koloni positif (terdapat koloni) dan negatif (tidak ada koloni) yang dapat dilihat pada Gambar 2.

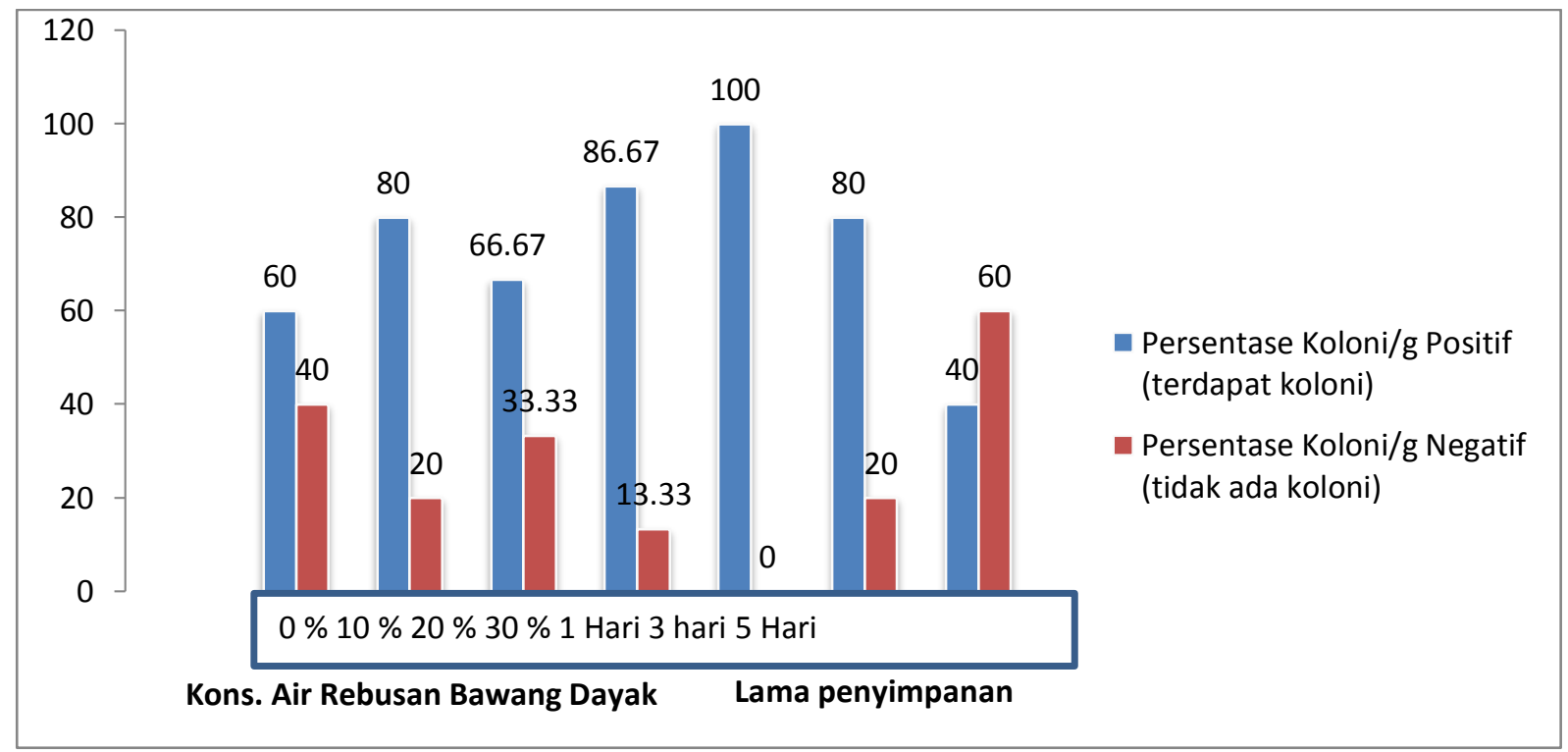

Gambar 2. Grafik persentase jumlah koloni/g bakteri E. coli (positif dan negatif) pada sampel daging yang direndam dengan ARBD.

Berdasarkan Gambar 2. diketahui bahwa perlakuan perendaman dengan konsentrasi ARBD menunjukkan bahwa persentase jumlah koloni yang positif pada perlakuan $30 \%$ sebesar $86.67 \%$ sedangkan yang terendah perlakuan $0 \%$ yaitu $60 \%$ dan yang negatif sebesar $40 \%$, walaupun $0 \%$ yang terendah koloni positifnya tetapi berdasarkan besaran jumlah koloninya $0 \%$ adalah yang terbanyak yaitu sebanyak 3 ulangan yang TBUD, $10 \%$ ada 1 ulangan TBUD dan $20 \%$ ada 3 ulangan TBUD sedangkan $30 \%$ masih bisa dihitung (Tabel 2). Berdasarkan hal tersebut menunjukkan ARBD konsentrasi $30 \%$ ada kecenderungan menurunkan total koloni bakteri E. coli namun belum maksimal. Berdasarkan hal tersebut menurut Naspiah, Iskandar dan Moelyomo (2014), bahwa ekstrak etanol umbi bawang tiwai mempunyai aktivitas anti bakteri terhadap beberapa bakteri, yaitu Bacillus subtilis, Bacillus pumilus, Escherichia coli, Micrococcusluteus, Methicillin-resistant Staphylococcusaureus (MRSA), Propionibacterium acne, Streptococcus pneumoniae, Salmonella typhi,
Staphylococcusaureus, dan Staphylococcus epidermidis.

\section{Kandungan fitokimia bawang dayak segar}

Berdasarkan pembahasan sebelumnya diketahui bahwa semakin tinggi konsentrasi pengawet alami semakin besar daya hambatnya. Kandungan fitokimia bawang dayak memiliki zat anti mikroba berupa saponin, alkaloid, flavonoid, triterpenoid, tannin, kuinon, polifenol, dan seskuiterpen. Anti mikroba tersebut masing-masing memiliki mekanisme untuk menghambat pertumbuhan bakteri. Menurut Firdaus (2015) bahwa mekanisme flavanoid sebagai anti bakteri yaitu dengan membentuk kompleks protein ekstra seluler sehingga dapat merusak membran sel, menghambat sistesis DNA dan RNA dan mengganggu metabolisme sel bakteri. Mekanisme triterpenoid yaitu dengan mengganggu proses terbentuknya dinding sel. Mekanisme tannin yaitu dengan menghambat enzim reverse transcriptase dan DNA topoisomerase, serta mengganggu pembentukan dinding sel bakteri seperti halnya triterpenoid, sedangkan mekanisme saponin sebagai anti mikroba yaitu mengganggu kestabilan membran 
sitoplasma dengan meningkatkan

permeabilitasnya sehingga terjadi kebocoran sel bakteri.

Konsentrasi ARBD $30 \%$ memiliki kecenderungan menurunkan jumlah koloni bakteri (Tabel 1) akibat daya hambat pertumbuhan mikroba cukup kecil. Hal ini dikarenakan saat ekstraksi dengan air salah satu zat anti mikroba tidak ditemukan atau negatif yaitu flavonoid. Berdasarkan penelitian Nur (2011) bahwa ekstraksi umbi bawang dayak segar dengan menggunakan beberapa pelarut dapat dilihat pada tabel 3 .

Tabel 3. Hasil uji fitokimia ekstrak umbi bawang dayak segar

\begin{tabular}{lccccc}
\hline \multirow{2}{*}{ Jenis Pengujian } & \multicolumn{5}{c}{ Hasil Pengujian } \\
\cline { 2 - 6 } & Air & Metanol & Etanol 96\% & Etilasetat & Heksan \\
\hline Alkaloid & ++ & + & + & ++ & + \\
Saponin & + & ++ & + & - & - \\
Tanin & + & ++ & ++ & - & - \\
Fenolik & ++ & +++ & +++ & ++++ & +++ \\
Flavonoid & - & ++ & +++ & + & - \\
Triterpenoid & +++ & +++ & ++++ & +++ & + \\
Steroid & + & + & + & + & + \\
Glikosida & + & ++ & +++ & ++++ & +++ \\
\hline Keterangan & $:$ & - = Negatif; + + positif lemah; $++=$ positif; $+++=$ positif kuat; ++++ = positif kuat sekali &
\end{tabular}

Berdasarkan Tabel 3 diketahui bahwa ektraksi bawang dayak segar menggunakan pelarut air menyebabkan tidak ditemukan kandungan flavonoid, padahal flavonoid memiliki peranan penting sebagai anti mikroba yaitu dengan membentuk kompleks protein ekstra seluler sehingga dapat merusak membran sel, menghambat sistesis DNA dan RNA dan mengganggu metabolisme sel bakteri. Itulah sebabnya ekstraksi bawang dayak dengan pelarut air $10 \%, 20 \%$ dan 30 $\%$ kurang menurunkan jumlah koloni bakteri akibat salah satu zat anti mikroba negatif sehingga aktivitas anti mikroba berkurang dan daya hambat menjadi kecil. Flavanoid juga menjadi penentu tinggi rendahnya aktivitas antioksidan suatu anti mikroba. Antioksidan tersebut bermanfaat untuk menangkal radikal bebas sehingga bahan pengawet ekstrak bawang dayak dapat dipergunakan sebagai bahan obat untuk meningkatkan kesehatan tubuh. Menurut Amic, Beslo dan Trinasjstic (2003) bahwa flavonoid merupakan salah satu dari kelompok senyawa fenolik yang dapat ditemukan di buah dan sayur. Flavonoid telah diteliti memiliki berbagai aktivitas biologis seperti antikanker, antiviral, antiinflamasi, mengurangi risiko penyakit kardiovaskuler dan penangkap radikal bebas. Kekuatan aktivitas antioksidan dari flavonoid bergantung pada jumlah dan posisi dari gugus -OH yang terdapat pada molekul. Semakin banyak gugus - $\mathrm{OH}$ pada flavonoid, maka aktivitas antiradikalnya semakin tinggi. Adanya gugus orto-katekol $(3,, 4,,-\mathrm{OH})$ pada cincin B flavonoid merupakan faktor penentu kapasitas antioksidan yang tinggi. Selanjutnya Pereira et al. (2009) dalam Yuswi (2017) bahwa senyawa flavonoid dan fenolik diperkirakan merupakan senyawa yang bertanggung jawab terhadap aktivitas antioksidan. Aktivitas antioksidan pada senyawa flavonoid, fenolik senyawa tersebut adalah senyawa-senyawa fenol, yaitu senyawa dengan gugus - $\mathrm{OH}$ yang terikat pada karbon cincin aromatik. Senyawa fenol ini mempunyai kemampuan untuk menyumbangkan atom hidrogen, sehingga radikal DPPH dapat tereduksi menjadi bentuk yang lebih stabil.

\section{Keadaan fisik daging setelah penyimpanan}

\section{Penyimpanan 1 hari}

Daging sapi yang telah direndam dengan ARBD dan disimpan selama 1 hari dapat dilihat pada Gambar 3. 

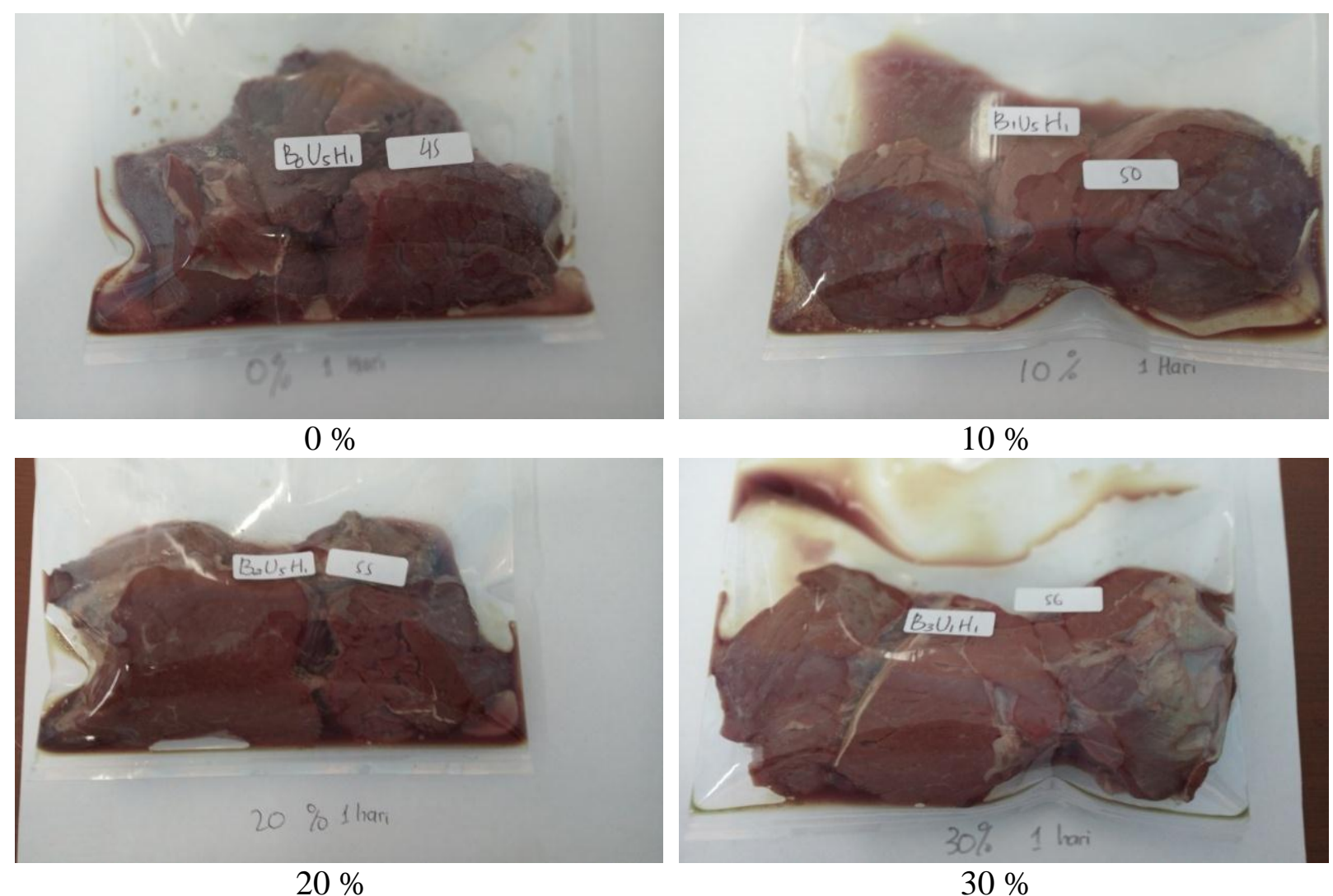

Gambar 3. Perendaman ARBD konsentrasi $0 \%, 10 \%, 20 \%$ dan $30 \%$ penyimpanan 1 hari

Berdasarkan Gambar 3. menunjukkan, daging ARBD konsentrasi 0\% terlihat lebih gelap, sedangkan pada daging ARBD dengan konsentrasi $10 \%, 20 \%$ dan $30 \%$ warna daging lebih terang serta tidak gelap. Hal ini disebabkan adanya pengaruh warna ARBD yang berwarna merah akibat adanya zat antosianin. Rein (2005) dalam Nur (2011) menyatakan bahwa antosianin adalah pigmen alami yang tersebar secara luas di alam. Senyawa antosianin merupakan subkelas dari flavonoid dan memberikan warna merah, ungu dan biru pada banyak bunga, buahbuahan dan sayuran. Stabilitas warna dari antosianin sangat dipengaruhi oleh $\mathrm{pH}$, jenis

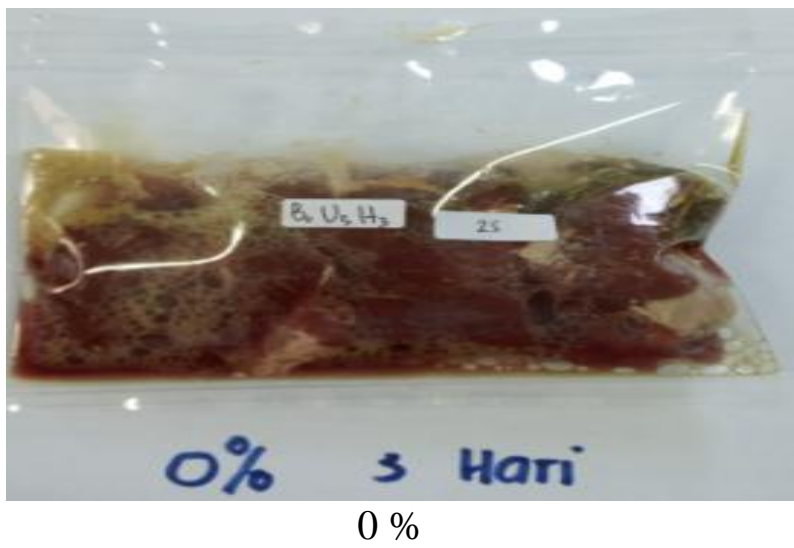

pelarut, temperatur, oksigen, cahaya dan enzim.

Fisik daging penyimpanan 1 hari masih terlihat segar dan tidak ada aroma busuk kecuali ARBD konsentrasi $0 \%$ sudah tercium aroma busuk. Hal ini disebabkan pada konsentrasi $10 \%, 20 \%$ dan $30 \%$ daging direndam dengan ARBD yang merupakan air rebusan yang mengandung zat pengawet anti mikroba/anti bakteri.

\section{Penyimpanan 3 hari}

Daging sapi yang telah direndam dengan ARBD dan disimpan selama 3 hari dapat dilihat pada Gambar 4.

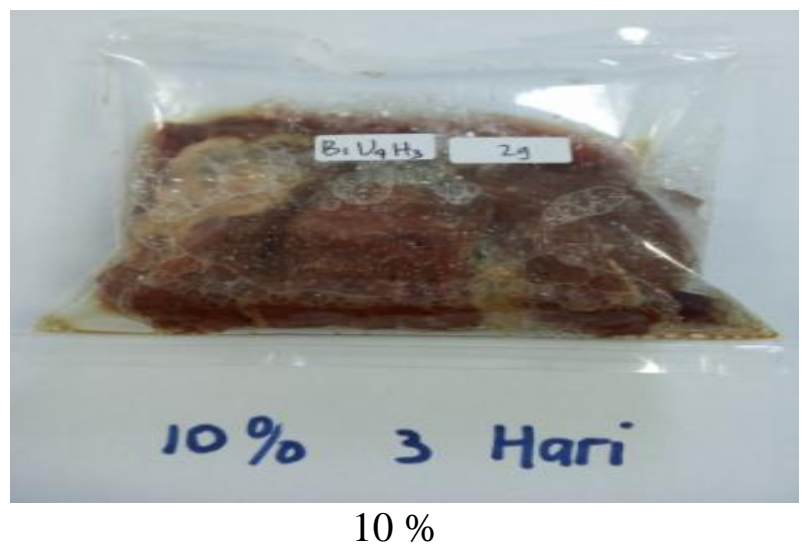




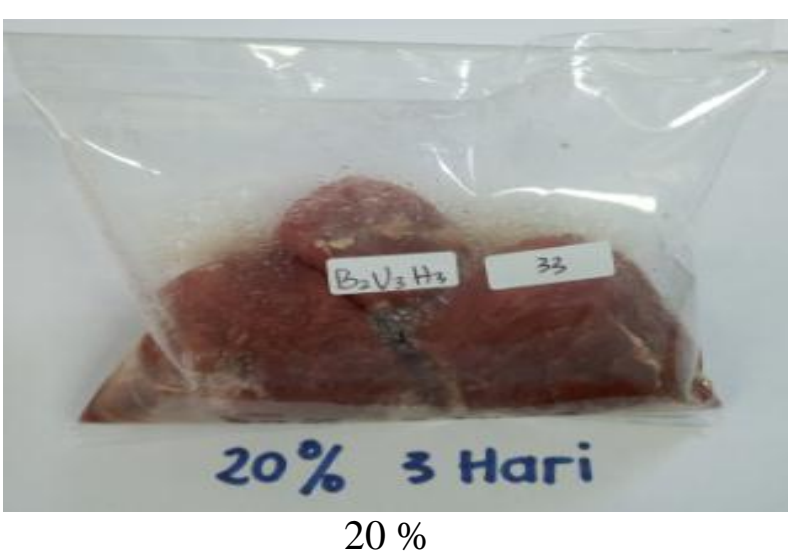

Gambar 4. Perendaman ARBD konsentrasi 0\%, $10 \%, 20 \%$ dan $30 \%$ penyimpanan 3 hari

Gambar 4 menunjukkan konsentrasi ARBD $0 \%$ dan $10 \%$ terlihat warna daging lebih gelap dan terdapat busa yang lebih banyak dibandingkan $20 \%$ dan $30 \%$. Menurut Arini (2017) bahwa pada makanan berprotein yang telah mengalami kerusakan warna berubah menjadi lebih gelap, berlendir, bau busuk dan rasa akan menjadi pahit. Berdasarkan literatur, makanan berprotein yang telah mengalami kerusakan menghasilkan bau busuk khas protein, tekstur lebih lembek dan berlendir (Purnawijayanti, 2001). Pada daging di bawahnya terdapat air berwarna cokelat. Selanjutnya Arini (2017) menyatakan bahwa mikroba dapat ditemukan di tanah, air, maupun udara yang dapat menyebabkan kerusakan pangan dan
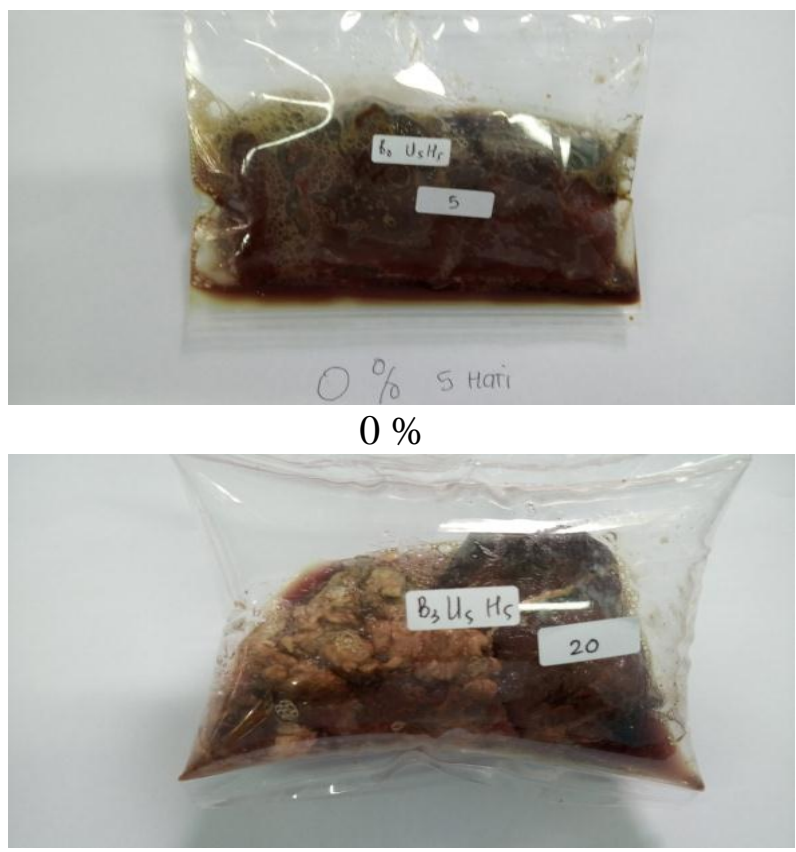

$20 \%$

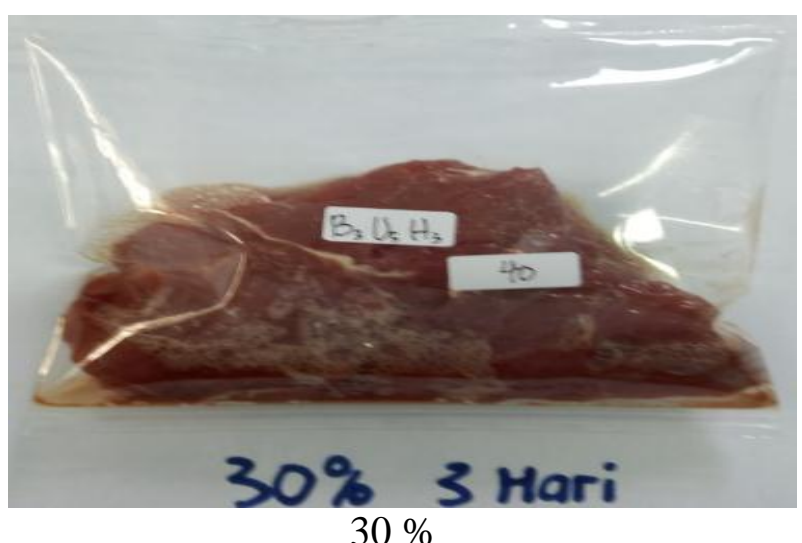

berbahaya bagi tubuh karena dapat menghasilkan racun. Mikroba dalam bahan pangan dapat mengubah komposisi bahan pangan dengan cara menghidrolisis pati dan selulosa menjadi fraksi yang lebih kecil, menghidrolisis lemak dan menyebabkan ketengikan, menyebabkan ferementasi gula serta merombak protein menjadi amoniak sehingga menghasilkan bau busuk. Beberapa mikroba dapat membentuk lendir, gas, busa warna, asam, toksin dan lain-lain.

\section{Penyimpanan 5 hari}

Daging sapi yang telah direndam dengan ARBD dan disimpan selama 5 hari dapat dilihat pada Gambar 5.
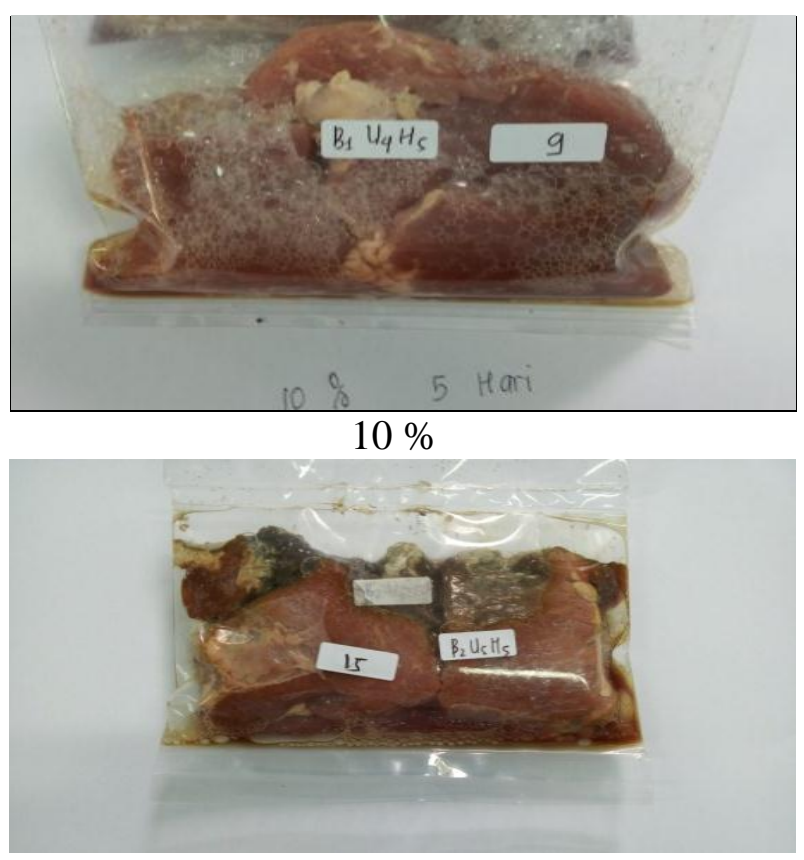

$30 \%$

Gambar 5. Perendaman ARBD konsentrasi $0 \%, 10 \%, 20 \%$ dan $30 \%$ Penyimpanan 5 hari 
Berdasarkan keadaan fisik daging setelah perendaman seperti terlihat pada Gambar 5 menunjukkan bahwa daging yang tidak direndam dengan ARBD konsentrasi 0 $\%$ berwarna kehijauan dan memiliki banyak busa dibandingkan daging ARBD konsentrasi $10 \%, 20 \%$ dan $30 \%$. Warna kehijauan pada konsentrasi ARBD $0 \%$ akibat adanya oksidasi atau adanya $\mathrm{H}_{2} \mathrm{~S}$ yang dihasilkan oleh bakteri Laktobacillus dan Leuconostok. Selain bakteri E. coli di duga terdapat bakteri lain yang menyebabkan pembusukan.

Daging pada penyimpanan 5 hari pada suhu kamar sudah terjadi pembusukan. Daging dengan konsentrasi ARBD $30 \%$ terjadi penggembungan pada plastik sampel yang menunjukkan terdapat gas oleh aktivitas mikroorganisme pembusuk. Hal ini menunjukkan efek anti mikroba dengan ARBD sudah hilang sehingga terjadi pembusukan oleh bakteri dan terjadi pembentukan gas oleh bakteri. Hasil penelitian Prihharsanti (2016) pengujian awal dengan Eber, menunjukkan bahwa daging yang dibiarkan pada suhu kamar sudah mulai melepaskan gas hasil pembusukannya pada jam ke 9. Pembusukan terjadi pada daging yang disimpan pada suhu kamar, karena mikroorganisme pembusuk dapat bermetabolisme tanpa hambatan. Enzim dapat bekerja optimal pada suhu kamar, karena suhu kamar rata-rata $28{ }^{\circ} \mathrm{C}$.

Daging di dalam plastik tertutup merupakan suatu medium terbatas untuk pertumbuhan mikroorganisme sehingga cadangan energi berupa nutrisi dan air, dapat sewaktu-waktu habis dan zat hasil sisa metabolisme berupa toksin, gas dan lain-lain menumpuk sehingga mempengaruhi kehidupan mikroorganisme, akibatnya sampai waktu tertentu mikroorganisme dalam medium pertumbuhannya melambat, ukuran sel mengecil dan ketika cadangan energi habis akan terjadi fase kematian. Hal ini jelas ditunjukkan pada penyimpanan 1 hari lalu menurun pada penyimpanan 3 hari dan makin menurun hingga mencapai 0 koloni pada penyimpanan 5 hari (Tabel 1). Hal ini sesuai dengan pernyataan Lestari et al. (2018) bahwa pertumbuhan mikrobia dibagi menjadi 4 fase yaitu fase lag, fase log, fase stasioner, dan fase kematian. Pada fase lag, sel tumbuh dengan sangat lambat dan hanya beberapa sel saja yang berkembang biak, selanjutnya pada fase logaritmik atau eksponensial, hampir semua sel berkembang biak dan kecepatan pertumbuhannya mengikuti kinetika reaksi orde pertama serta dapat digunakan untuk menentukan waktu generasi, setelah itu kecepatan pertumbuhan sel akan menurun dan memasuki fase stasioner. Pada tahap ini, karena keterbatasan nutrisi dan akumulasi produk samping, maka sebagian sel akan mati dan sebagian sel akan berkembang biak agar populasi sel tetap stabil. Setelah fase stasioner, populasi memasuki fase kematian dimana kecepatan kematian sel lebih tinggi dibandingkan kecepatan pertumbuhan sel.

\section{KESIMPULAN}

Air Rebusan Bawang Dayak $30 \%$ memiliki kecenderungan untuk menurunkan jumlah koloni bakteri Escherichia coli sedangkan perlakuan penyimpanan yang terbaik adalah 1 hari masih dalam kondisi baik dan tidak busuk.

\section{SARAN}

Perlu adanya penelitian lanjutan untuk menambah kegunaan bawang dayak sebagai anti mikroba pada pengawetan pangan serta pentingnya melanjutkan penelitian ke perlakuan air rebusan bawang dayak di atas konsentrasi $30 \%$.

\section{UCAPAN TERIMA KASIH}

Terima kasih yang sebesar-besarnya kepada Kemenristek Dikti dan STIPER Kutai Timur atas terlaksananya penelitian ini dengan baik. Terima kasih pula kepada Kepala Laboratorium dan segenap staf di UPTD Laboratorium Kesehatan Hewan dan Kesehatan Masyarakat Veteriner (Keswan dan Kesmavet) Samarinda yang telah 
memberikan izin untuk melaksanakan analisis uji E.coli.

\section{DAFTAR PUSTAKA}

Amic, D., Davidović-Amić, D., Bešlo, D., \& Trinajstić, N. (2003). Structure-radical scavenging activity relationships of flavonoids. Croatica Chemica Acta, 76(1), 55-61.

Arini, L. D. D. (2017). Faktor-faktor penyebab dan karakteristik makanan kadaluarsa yang berdampak buruk pada kesehatan masyarakat. Jurnal Teknologi dan Industri Pangan, 2(1), 15-24. https://doi.org/10.33061/jitipari.v2i1.15 31

Badan Standardisasi Nasional. (2009). SNI 7388: 2009 tentang batas maksimum cemaran mikroba dalam pangan. http://blog.ub.ac.id/cdrhprimasanti90/ files/2014/03/SNI-7388-2009-Batasmaksimum-cemaran-mikroba-dalampangan.pdf.

Firdaus, T. (2015). Efektivitas ekstrak bawang dayak (eleutherine palmifolia) dalam menghambat pertumbuhan bakteri staphylococcus aureus [Thesis, Universitas Islam Negeri Syarif Hidayatullah].

http://repository.uinjkt.ac.id/dspace/han dle/123456789/27277

Istiansyah, A., Rahmawati, D., \& Ibrahim, A. (2016). Aktivitas anti bakteri ekstrak etanol bawang tiwai (Eleutherine americana Merr.) terhadap bakteri Staphylococcus aureus dan Escherichia coli. Proceeding of Mulawarman Pharmaceuticals Conferences, 3, 2932. https://doi.org/10.25026/mpc.v3i2.85

Koeswara, S. (2009). Pengawet alami untuk produk dan bahan pangan. Ebookpangan.com.

Lestari, L. A., Harmayani, E., Utami, T., Sari, P. M., \& Nurviani, S. (2018). Dasar mikrobiologi makanan di bidang gizi dan kesehatan. Gadjah Mada University Press.

Naspiah, N., Iskandar, Y., \& Moektiwardoyo, M. (2014). Artikel ulasan: Bawang tiwai (Eleutherine americana merr.), tanaman Multiguna. Indonesian Journal of Applied Sciences, 4(2). https://doi.org/10.24198/.v4i2.16820

Nur, A. M., \& Astawan, M. (2011). Kapasitas antioksidan bawang dayak (Eleutherine palmifolia) dalam bentuk segar, simplisia dan keripik, pada pelarut nonpolar, semipolar dan polar. Fakultas Teknologi Pertanian Institut Pertanian Bogor.

Prihharsanti, A. H. T. (2016). Populasi bakteri dan jamur pada daging sapi dengan penyimpanan suhu rendah. Sains Peternakan: Jurnal Penelitian Ilmu Peternakan, 7(2), 66-72. https://doi.org/10.20961/sainspet.v7i2.1 060

Purnawijayanti, H. A. (2001). Sanitasi higiene dan keselamatan kerja dalam pengolahan Makanan. Kanisius.

Purnomo, H. (2012). Teknologi pengolahan dan pengawetan daging. Universitas Brawijaya Press.

Puspadewi, R., Adirestuti, P., \& Menawati, R. (2013). Khasiat umbi bawang dayak (Eleutherine palmifolia (L.) Merr.) sebagai herbal anti mikroba kulit. Kartika: Jurnal Ilmiah Farmasi, 1(1), 31-37. https://doi.org/10.26874/kjif.v1i1.21

Saparinto, C., \& Hidayati, D. (2006). Bahan tambahan pangan. Kanisius.

Sutiknowati, L. I. (2016). Bioindikator pencemar, bakteri Escherichia coli. Jurnal Oseana, 41(4), 63-71.

Yuniar, R., \& Galingging. (2009). Bawang dayak (Eleutherine palmifolia) sebagai tanaman obat multifungsi. Warta Penelitian dan Pengembangan, 15(3), 2-4.

Yuswi, N. C. R. (2017). Ekstraksi antioksidan bawang dayak (Eleutherine palmifolia) dengan metode ultrasonic bath (kajian jenis pelarut dan lama ekstraksi). Jurnal Pangan dan Agroindustri, 5(1). https://jpa.ub.ac.id/index.php/jpa/article /view/499 